\title{
Parapoxvirus Papillomatosis in the Muskoxen (Ovibos moschatus): Genetical Differences between the Virus Causing New Outbreak in a Vaccinated Herd, the Vaccine Virus and a Local Orf Virus
}

\author{
By Ugo Moens, Inger Wold, Svein D. Mathiesen, Trond Jørgensen, \\ Dag Sorensen and Terje Traavik
}

Virological Research Group and Department of Arctic Biology, Institute of Medical Biology and Foundation of Applied Research, University of Tromsø, Tromsø, Norway.

\begin{abstract}
Moens, U., I. Wold, S. D. Mathiesen, T. Jørgensen, D. Sørensen and T. Traavik: Parapoxvirus papillomatosis in the muskoxen (Ovibos moschatus): Genetical differences between the virus causing new outbreak in a vaccinated herd, the vaccine virus and a local orf virus. Acta vet. scand. 1990, 31, 17-25. - Since 1981 a domesticated muskoxen herd had been successfully vaccinated against papillomatosis with homogenated, glutaraldehyde inactivated papilloma tissue. In the fall of 1985 a new clinical outbreak of disease occurred, affecting previously infected as well as vaccinated animals.

The purification of parapox virions directly from papilloma tissue and orf scabs collected in a local sheep farm was followed by restriction endonuclease analysis of viral DNA. The morphological identity of purified virus was controlled by electron microscopy. Comparison of restriction endonuclease digests (10 different enzymes) by gel electrophoresis demonstrated that the muskoxen parapoxvirus from the new outbreak 1985 differed considerably from the 2 other isolates (muskoxen 1981 and local orf). The latter viruses demonstrated a high degree of homology, but differences were evident after digestion with the enzyme EcoRI. During metrizamide gradient purification minor bands containing morphologically intact virions were isolated in addition to the major fractions. The restriction enzyme digests indicated that the virions of the minor bands differed from those in the major bands.
\end{abstract}

Papilloma tissue; orf scabs; virus purification; DNA isolation; rutrictions endonuclease analysis.

\section{Introduction}

Related parapoxviruses infect and produce lesions (papilloma or ecthyma) in various wild and domestic ruminants. Man can become accidentally infected. The virus genome typically consists of a linear, doublestranded, terminally cross-linked DNA with molecular weight $85-90 \times 10^{6}$ daltons (Menna et al. 1979, Robinson et al. 1982, Mercer et al. 1987, Robinson et al. 1987).
Restriction enzyme analysis of parapoxvirus DNA from various sources and parts of the world reveals marked heterogeneity, suggesting the co-existence of different strains within the same area (Robinson et al. 1982, Wittek et al. 1980, Rafii \& Burger 1985). For orf virus isolates from sheep and goats this conclusion is supported by cross neutralization tests in cell culture (Precausta \& Stellman 1973, Wittek et al. 1980). 
A virus with typical parapox morphology causes a sometimes explosively proliferating papillomatosis in muskoxen (Ovibos moschatus) (Kummeneje \& Krogsrud 1978, Mathiesen et al. 1985).

The only captive muskoxen herd in Norway was haunted by papillomatosis between 1969 and 1981. Some years the majority of newborn calves succumbed until in 1981 an effective vaccine was developed. No clinical cases were observed in the immunized herd during the years 1982-84, neither were any symptoms observed among the calves born during the spring of 1985 . The natural history of papillomatosis in the muskoxen herd, the isolation of parapoxvirus and the development of an effective vaccine was described by Mathiesen et al. (1985). Serological studies indicated close antigenic relationship, but also differences between the $1981 \mathrm{mu}$ skoxen vaccine virus and an orf virus strain originating in Germany (Traavik et al. unpublished results).

During the fall 1985 a new outbreak of papillomatosis occurred in the muskoxen herd. Animals that had been previously naturally infected as well as earlier vaccinated animals and newly vaccinated calves were affected, with the exception of 3 pregnant females.

Virus particles were isolated and purified from muskoxen papilloma tissue harvested for vaccine production in 1981, from processes collected during the 1985 outbreak and from orf scabs originating in a local sheep farm. In this communication we report the comparison of the 3 parapoxvirus strains on the basis of fingerprints obtained after digestion of viral DNA with 12 different restriction endonucleases.

\section{Materials and methods}

Virus infected tissue

In 1981 papilloma tissues were taken by surgery from various animals, pooled and used for vaccine production (Mathiesen et al. 1985). In 1985 papilloma tissue was taken from the hooves of a muskoxen calf born the same year. Orf scabs were collected in a sheep farm during veterinary treatment. Scabs were pooled from about 10 animals. All samples were kept at $-70^{\circ} \mathrm{C}$ until processing for virus isolation took place.

\section{Purification of virus}

Purification was adapted according to the method used sy Esposito et al. (1978). Tissues were homogenized in TE-buffer (25 mmol/1 Tris. $\mathrm{HCl}, \mathrm{pH} 7.6,10 \mathrm{mmol} / \mathrm{l}$ EDTA) by using a mortar and pestle. The cell debris was pelleted by centrifugation at $5000 \mathrm{rpm}$ for $10 \mathrm{~min}$. in a Sorvall SS34 rotor. The supernatants were centrifugated through a cushion of $4 \mathrm{ml} 40 \%$ sucrose solution made in TE-buffer in a Beckman SW 27 rotor at $21000 \mathrm{rpm}$ for $45 \mathrm{~min}$.

The resulting pellet was resuspended in 1-2 $\mathrm{ml}$ TE-buffer and loaded onto a chilled metrizamide (Nyegaard \& Co. AS, Oslo. Norway) density gradient. Gradients were constructed in SW 27 tubes as follows: a $20 \mathrm{ml} \mathrm{li-}$ near gradient of metrizamide (25 to $50 \%$ w/v) in TE-buffer was formed atop a $2 \mathrm{ml}$ cushion of $50 \% \mathrm{w} / \mathrm{v}$ metrizamide in TE-buffer and chilled to $4^{\circ} \mathrm{C}$. Just before the sample was applied, the gradients were overlaid with $3 \mathrm{ml}$ of cold $10 \%$ dextran (Pharmacia) in TE-buffer. Virions were centrifugated to equilibrium at $21000 \mathrm{rpm}$ for $18 \mathrm{hr}$ at $4^{\circ} \mathrm{C}$ in Beckman SW 27 rotor. The virus band was harvested and diluted 4 times in TE-buffer. Diluted virus particles were collected by centrifugation through an $8 \mathrm{ml}$ cushion of $40 \%$ $(\mathrm{w} / \mathrm{v})$ sucrose in $0.1 \times \mathrm{TE}$-buffer at 21000 rpm for $34 \mathrm{~min}$ in a SW 27 rotor. The pellet of purified virions was resuspended in a small volume of cold TE-buffer. 


\section{Electron microscopy}

Transmission electron microscopy after negative staining of purified virions was performed by standard methods. Briefly, $50 \mu \mathrm{l}$ purified virus was thoroughly mixed with 50 $\mu 1$ 3\% PTA (phosphotungstic acid, pH 6.5). One to 2 drops of the mixture was applied to a carbon-coated Formvar copper grid. After $1 \mathrm{~min}$ the fluid was retracted, and the grid was inspected in a JEOL (JEM 1200 EX) electron microscope.

\section{Protein concentration of purified virions}

Protein concentration was measured according to the method of Bradford (1976).

\section{Isolation of viral DNA}

Purified virions suspended in cold TE-buffer were adjusted to contain $50 \mu \mathrm{g} / \mathrm{ml}$ Proteinase $\mathrm{K}$ (Boehringer), 2\% N-lauryl sarcosinate (Sigma) and $50 \mathrm{mmol} / \mathrm{l} 2$-mercaptoethanol (Sigma). The mixture was incubated at $4^{\circ} \mathrm{C}$ for $30 \mathrm{~min}$ and then at $37^{\circ} \mathrm{C}$ for $4 \mathrm{~h}$. The mixture was adjusted to contain $1 \mathrm{~mol} / \mathrm{l}$ $\mathrm{NaCl}$. The digested virions were extracted twice with phenol-chloroform and twice with chloroform (chloroform-isoamylalcohol 24:1). The DNA was precipitated at $20^{\circ} \mathrm{C}$ by adding 2 volumes of ethanol. The DNA was pelleted by centrifugation for 30 min at $10000 \mathrm{rpm}$ at $4^{\circ} \mathrm{C}$ in a Sorvall SS34 rotor. The pellet was vacuumdried and resuspended in a small volume of $10 \mathrm{mmol} / \mathrm{l}$ Tris. $\mathrm{HC1}, \mathrm{pH}$ 7.5. DNA concentration and purity was measured with spectrophotometer (type HITACHI 150-20 double seam).

\section{Restriction endonuclease digests}

The restriction enzymes $\mathrm{Bg} 1 \mathrm{I}, \mathrm{CvnI}$ (= MstII) and DraI were purchased from Bethesda Research laboratories; Bg1II and PstI KpnI from Pharmacia; PvuII from Toyobo, and BamHI, EcoRI, HindIII and SalI were from Amersham. Enzymes were used as re- commended by Maniatis et al. (1982). Digestions were incubated for $4-5 \mathrm{~h}$ at $37^{\circ} \mathrm{C}$. Loading buffer (6X: $0.25 \%$ bromophenolblue, $40 \%(\mathrm{w} / \mathrm{v})$ sucrose in $\left.\mathrm{H}_{2} \mathrm{O}\right)$ was added before loading on gel. Digestions were run in the presence of a molecular marker $(\lambda /$ HindIII$\varnothing \times 174 /$ HaellI: Pharmacia, range $23 \mathrm{~kb}$ $0.2 \mathrm{~kb}$ ).

\section{Agarose gel electrophoresis}

The DNA fragments generated by restriction endonuclease cleavage were separated on $0.6 \%$ agarose gels (Pharmacia). Electrophoresis was carried out in a Tris-acetate buffer ( $0.04 \mathrm{~mol} / 1$ Trisacetate $0.001 \mathrm{~mol} / 1$ EDTA) according to Maniatis et al. (1982) and were visualized under ultraviolet light after staining with ethidium bromide $(0,5 \mu \mathrm{g} / \mathrm{ml})$ for $45 \mathrm{~min}$. The gels were photographed with Polaroid Type 55 film.

\section{Results}

\section{Purification of virions}

Virions from infected tissues were isolaed by a method adapted from Esposito et al. (1978). Following preliminary experiments we decided to use a metrizamide in stead of sucrose gradients (Joklik 1962) because during the latter procedure a substantial amount of virus was lost as large virus aggregates. This was also observed by Esposito et al. (1978) for orthopox and by Robinson et al. (1982) for parapox virus.

For sheep- and muskoxen-infected material (from 1985) 2 virus bands were obtained after metrizamide density gradient centrifugation. Similar results have been obtained for orf virus, (Robinson et al. 1982) and vaccinia virus (Westwood et al. 1964). A minor band was located below the main band in the gradient. By electron microscopy no obvious morphological differences were observed between virions from the major and minor 
bands. The protein concentrations of purified materials are shown in Table 1.

Table 1. Protein concentrations of purified viral material isolated from the infected muskoxes and sheep papilloma tissue.

\begin{tabular}{lc}
\hline $\begin{array}{l}\text { Source of purified } \\
\text { material }\end{array}$ & $\begin{array}{c}\text { Protein concentration } \\
\mathrm{mg} / \mathrm{ml}\end{array}$ \\
\hline $\begin{array}{l}\text { Muskoxen 1981 } \\
\text { Muskoxen 1985, minor band }\end{array}$ & 230 \\
Muskoxen 1985, major band & $105-167$ \\
Sheep 1985, minor band & $385-654$ \\
Sheep 1985, major band & $131.5-165$ \\
\hline
\end{tabular}

After purification of virions from muskoxen papilloma tissue the bands had approximately the same protein concentration. For sheep materials, however, the major band contained about 3-4 times as much protein. But contaminating tissue proteins might be present to different degrees.

\section{Electron microscopy of purified virions}

Electron microscopy studies of both virions isolated from muskoxen and sheep have revealed the characteristic ovoid shape for poxviruses and a size of approximately $160 \times 360 \mathrm{~mm}$ (results not shown).

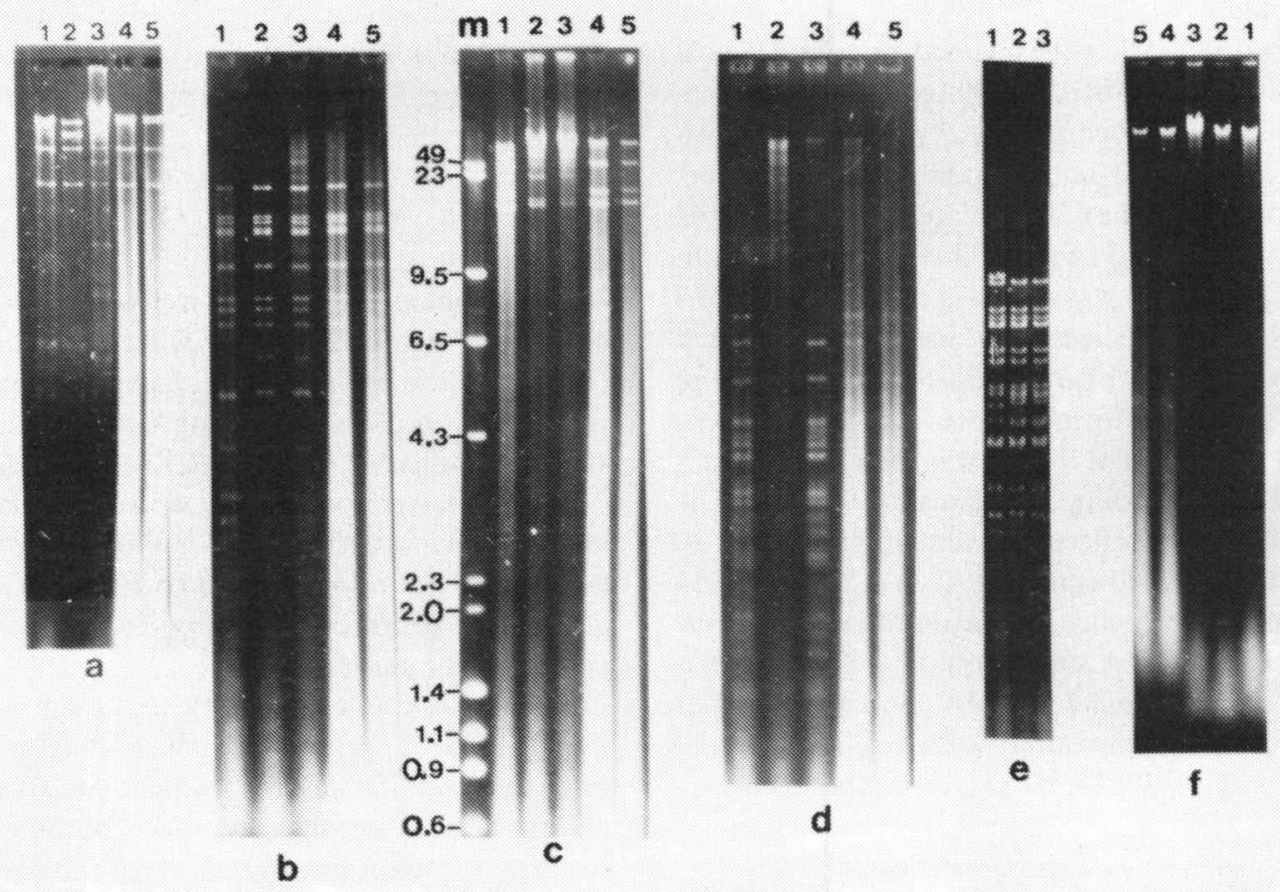

Figure 1. Gel electrophoresis of viral DNA fragments obtained after restriction endonucleases digests. Lane 1: muskoxen parapoxvirus DNA from 1981 material; lane 2: muskoxen parapoxvirus DNA from 1985 material, minor band; lane 3: as in lane 2 but major band fraction; lane 4: viral DNA from sheep material, minor band; lane 5: as in lane 4 but major band fraction, $m$ : molecular size marker ( $\lambda$-HindIII/ØX-174 HaelII). The size of the fragments of the marker are indicated in kilobases. Gels were run overnight at $25 \mathrm{~V}$. The restriction enzymes used are: BamHI (a); BglII (b); CvnI (c): PstI (d); PvuII (e); none (f). 
Electrophoretic analysis of restriction endonuclease digests

The electrophoretic migration pattern of endonuclease-digested viral DNAs are shown in Figs. 1-4.

The different enzymes produced patterns that fitted into the following scheme.

a) Muskoxen parapoxvirus 1981 is identical with sheep virus, and muskoxen virus 1985 is substantially different.

Such patterns were found with the re- striction endonucleases BamHI, Bg1I (results not shown), Bg1II, CvnI (= MstII), PstI and PvuII. With BamHI digestion an additional band of more than $23 \mathrm{~kb}$ was found for muskoxen 1985. With Bg1II heterology was most obvious for the middle size fragments ( $6 \mathrm{~kb}-2 \mathrm{~kb})$. An additional DNA fragment of about $5 \mathrm{~kb}$ was present for muskoxen 1986 in the Bg1 II pattern. CvnI (= MstII) gave discrepancies in the heavy DNA fragments.
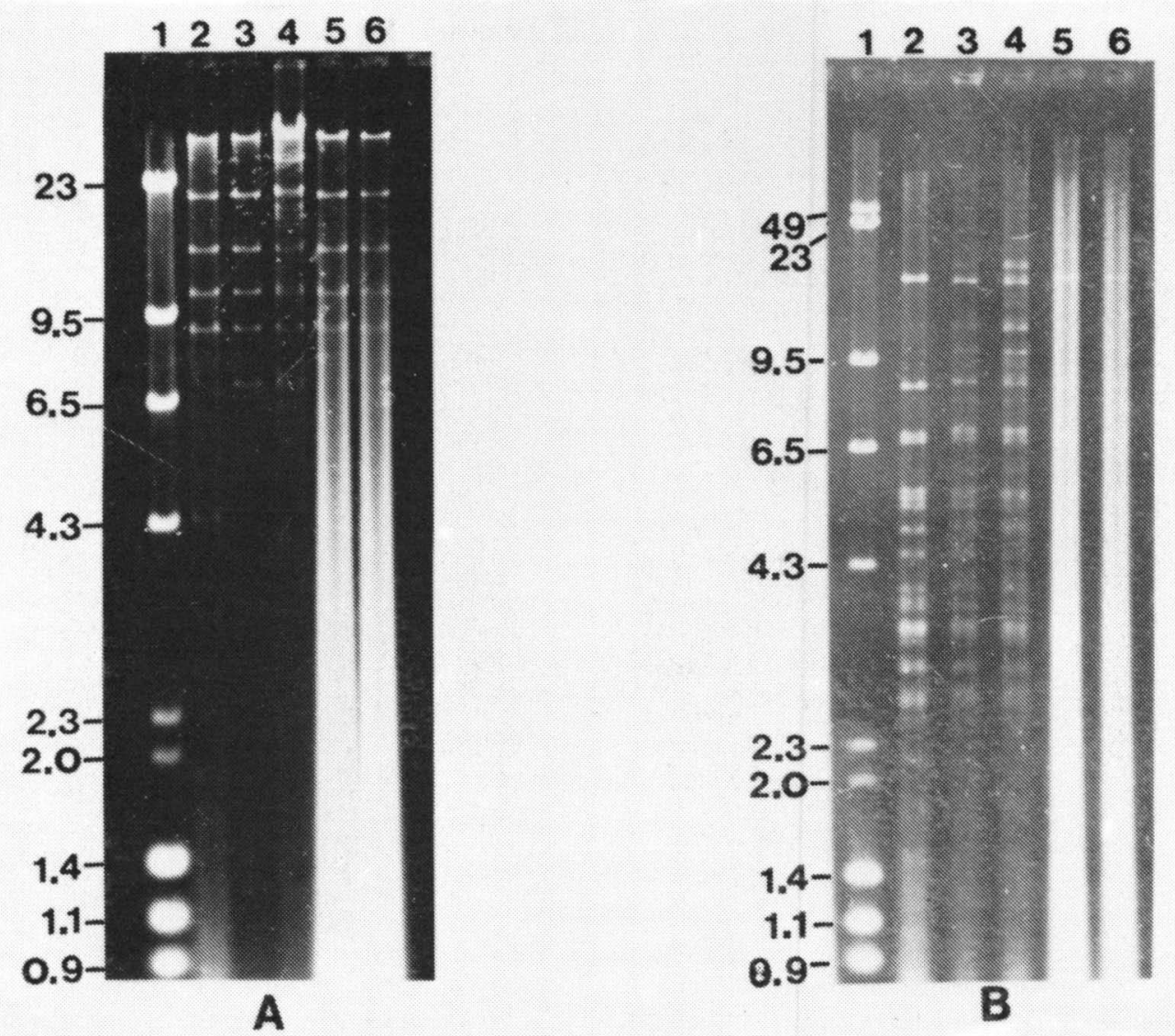

Figure 2. Gel electrophoresis of viral DNA digested with the restriction endonucleases HindIII and Sall.

2a: HindIII digest. Lane 1: molecular size marker (see legend figure 2); lane 2-6: the order of the samples is the same as in figure 1.

$2 \mathrm{~b}$ : Sall digest. The order of the samples is the same as in $2 \mathrm{a}$. 
After PstI digestion the most striking difference was the loss of an approximately 7 kb DNA fragment for muskoxen 1985 (see Fig. 1). PvulI digestion gave analogous results, but here sheep (data not shown) and muskoxen 1981 shared an additional high molecular weight band of about $9.5 \mathrm{~kb}$.

b) The patterns for viral DNAs from major and minor band differ, otherwise the conclusions are as in a).

This was observed for the restriction en-

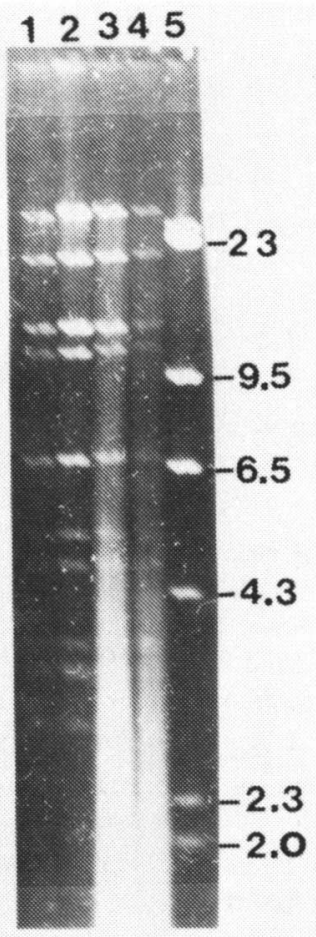

Figure 3. Gel electrophoresis of viral DNA fragments after Dral endonuclease digest. Lane 1: muskoxen parapoxvirus DNA from 1985 material, minor band; lane 2: muskoxen parapoxvirus DNA from 1985 material, major band; lane 3: viral DNA from sheep material 1985, minor band and lane 4: the same material but from the major band. Lane : molecular size marker ( $\lambda$-HindIII/ØX174-HaeIII). donucleases HindIII and Sa1I. For HindIII muskoxen 1985 has an additional DNA fragment of about $6.5 \mathrm{~kb}$ and lacks a $4.4 \mathrm{~kb}$ fragment. Muskoxen 1985 major band virions demonstrated 2 additional DNA fragments of about $20 \mathrm{~kb}$.

After SalI digestion, muxkoxen 1981 and sheep viruses are lacking DNA fragments in the range 9-11 kb. Muskoxen $1985 \mathrm{mi}$ nor band virions lack a heavy size DNA fragment (about $20 \mathrm{~kb}$ ) compared with major band viral DNA. The digests are shown in Fig. 2.

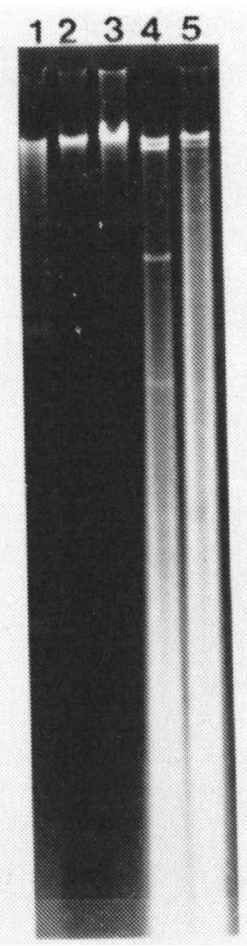

Figure 4. Restriction pattern after digestion with EcoRI. The order of the samples is in lane 1: muskoxen parapoxvirus DNA from 1981 material; lane 2: muskoxen parapoxvirus DNA from 1985 material, minor band; lane 3: as in 3 but major band fraction; lane 4: viral DNA from sheep material, minor band; lane 5: as in 4 but minor band fraction. 
c) All 3 viruses give identical fingerprints. This was observed for the enzyme DraI in spite of the fact that quite a few DNA fragments were generated after digestion. This is presented in Fig. 3.

d) The sheep virus is different from the muskoxen isolates, and the latter are identical.

These patterns were observed after Eco$R I$ digestion (Fig. 4). DNA isolated from sheep virus generated three additional bands of about $6.5,12 \mathrm{~kb}$ and a very heavy one.

\section{Estimation of the size of the total genome}

The DNA fragments generated by restriction endonuclease cleavage were run on $0.6 \%$ agarose gels in the presence of suitable molecule or weight markers ( $\lambda$ DNA-HindIII/ ØX174 DNA-HaelII; Pharmacia). After restriction enzyme digestion the sum of viral DNA fragments amounted to more than 100000 base pairs, corresponding to a molecular weight of more than $67 \times 10^{6} \mathrm{D}$.

\section{Discussion}

The experiments described in this article demonstrate considerable differences in the genomes of parapoxviruses isolated from muskoxen papillomatosis cases in 1981 and 1985. Although the exact locations of differing sequences and the antigenic consequences of the genetic heterogeneity have not been established, it seems justified to conclude that a "new « virus caused the papillomatosis outbreak in earlier infected and immunized muskoxens.

The origin of the »new « parapoxvirus is still uncertain. The muskoxen isolate from 1981 shows a high degree of homology with the local sheep strain from 1985. Published sheep and muskoxenparapoxvirus restriction enzyme fingerprints from other parts of the world (Rafii \& Burger 1985, Mercer et al.
1987, Robinson et al. 1987) indicate striking homologies with both of these isolates. Two major possibilities seem to exist. A new local sheep virus strain may have been brought into the muskoxen herd in 1985 . Alternatively, the parapoxvirus may have been subclinically infecting the immunized herd and mutating until it could escape the immunological suppression. Work in progress will address these possibilities.

Virion purification by metrizamide was preferred in stead of sucrose gradient centrifugation (Joklik 1962). The latter procedure resulted in a subtantial loss of virus due to the formation of large aggregates. From sheep scabs and muskoxen 1985 papilloma tissue, parapox virions were separated in 2 different bands after metrizamide density gradient centrifugation. This has also been observed during purification of other poxviruses (Robinson et al. 1982, Westwood et al. 1964). The lower (usually minor) band may contain damaged virions or virions with altered composition in nucleic acid, proteins or lipids. In this study it was shown that for muskoxen 1985 virus, the virions of the 2 bands contained DNA with different restriction endonuclease fragment patterns, although this was not detected with all the endonucleases used. It will be interesting to test and compare the infectivity of the virions from both bands. For the local sheep (orf) virus no such differences were found with any enzyme.

The molecular weight of the genomes of the parapoxviruses described here was estimated to be more than $67 \times 10^{6} \mathrm{D}$. The theoretical molecular weight for other parapoxviruses was calculated to be in the range of 85 $88 \times 10^{6} \mathrm{D}$ (Robinson et al. 1982, Thomas et al. 1980, Menna et al. 1979).

The work described in this article was performed with parapoxviruses isolated directly from naturally infected tissues, while most 
earlier studies were done with cell culturepropagated virus. This may be an important consideration given the chance that cell culture propagation may select members of the total virus population that are not necessarily the most important pathogenically.

It would be of significant economical importance if a general vaccine against parapoxviruses, especially orf virus, could be prepared. The main obstacle in this connection could be the genetical, and probably also antigenic, heterogenity of virus strains demonstrated by this and other studies. Careful dissection and comparison of viral DNA and expression products is necessary in order to approach the probability of constant antigenic epitopes of biological/protective relevance.

\section{Acknowledgements}

The authors wish to thank Henny Johansen for preparing the manuscript. The work is supported by grant from the Norwegian Research Council for Science and the Humanities.

\section{References}

Bradford MM: A rapid sensitive method for the quantitation of microgram quantities of protein utilizing the principle of proteindye binding. Anal. Bioch. 1976, 72, 248-254.

Esposito JJ, Obijeski JF, Nakano JH: Orthopoxvirus DNA: Strain differentiation by electrophoresis of restriction endonuclease fragmented virion DNA. Virology 1978, 89, 53-66.

Joklik WK: The purification of four strains of poxvirus. Virology 1962, 18, 9-18.

Kummeneje K, Krogsrud J: Contagious ecthyma (Orf) in muskoxen (Ovibos moschatus). Acta vet. scand. 1978, 19, 461-462.

Maniatis T, Fritseh EF, Sambrook J: Molecular Cloning: A laboratory Manual. Cold Spring Harbor Laboratory Press, Cold Spring Harbor, N.Y. 1982.

Mathiesen SD, Jergensen T, Traavik T, Blix AS: On contagious ecthyma and its treatment in muskoxen (Ovibos moschatus). Acta vet. scand. 1985, 26, 120-126.
Menna A, Wittek R, Bachman PA, Mayr A, Wyler $R$ : Physical characterization of a stomatitis papulosa virus genome: A cleavage map for restriction endonucleases HindIII and EcoRI. Arch. Virol. 1979, 59, 145-156.

Mercer AA, Fraser $K$, Barns G, Robinson AJ: The structure and cloning of orf virus DNA. Virology 1987, 157, 1-12.

Precausta $O$, Stellman $C$ : Isolation and comparative study "in vitro" of five strains of contagious echtyma virus of sheep. Zbl. Vet. Med. 1973, 20, 340-355.

Rafii $F$, Burger D: Comparison of contagious ecthyma virus genomes by restriction endonucleases. Arch. Virol. 1985, 84, 283-289.

Robinson AJ, Ellis G, Balalssu T: The genome of Orf virus: Restriction Endonuclease analysis of viral DNA isolated from lesions of Orf in sheep. Arch. Virol. 1982, 71, 43-55.

Robinson AJ, Barns G, Fraser K, Carpenter E, Mercer $A A$ : Conservation and variation in orf virus genomes. Virology 1987, 157, 13-23.

Thomas V, Flores L, Holowczak: Biochemical and electron microscopic studies of the replication and composition of milker's node virus. J. Virol. 1980, 34, 244-255.

Westwood JCN, Harris WJ, Zwartouw HT, Titmuss $D M$, Appleyard GJ: Studies on the structure of vaccinia virus. J. gen. Microbiol. 1964, 34, 67 78.

Wittek R, Herlyn R, Schümperli D, Bachmann PA, Mayr $A$, Wyler $R$ : Genetic and antigenic heterogenity of different parapoxvirus strains. Intervirology $1980,13,33-41$.

\section{Sammendrag}

Parapox papillomatose i moskus (Ovibus moschatus): Genetiske forskjeller mellom virus som fordrsaker nytt uttbrudd $i$ vaksinerte dyr, vaksine viruset og et lokalt orf virus.

Siden 1981 ble en gruppe domestiserte moskusokser gitt god beskyttelse mot papillomatose gjennom vaksinering med et homogenat av glutaraldehyd inaktivert papilloma vev. Høsten 1985 skjedde et nytt utbrudd av sykdommen som ogsả berørte tidligere infiserte og vaksinerte dyr.

Parapoxvirioner renset direkte fra papillomavev og munnskurv (Ecthyma contagiosum) fra sauer pá et 
lokalt gårdsbruk ble brukt til restriksjonsenzymanalyse av viralt DNA. Den morfologiske identiteten til renset virus ble verifisert gjennom elektronmikroskopiske undersøkelser. Sammenligninger av restriksjonsenzym spaltet DNA (10 forskjellige enzymer) separert ved gelelektroforese viste at parapox virus fra det nye utbruddet i 1985 var klart forskjellig fra de 2 andre isolatene (moskusokser fra 1981 og sau). De sistnevnte hadde derimot en høy grad av homologi, men noen forskjeller kom fram ved spalting med enzymet EcoRI. Ved metrizamid gradient rensing av virus fra alle 3 isolater ble det $i$ tillegg til hovedfraksjonen isolert morfologiske intakte virus fra et mindre band. Restriksjonsenzymspalting indikerte at virus fra de minste bandene var forskjellig fra hovedfraksjonene.

(Received November 9, 1988; accepted May 1, 1989).

Reprints may be requested from: T. Traavik, University of Tromsø, Institute of Medical Biology, N-9001 Tromsø, Norway. 